\title{
Mini review: Application of supercritical carbon dioxide in extraction of propolis extract
}

\author{
Nor Faadila Mohd Idrus a, b, Lee Nian Yian a, Zuhaili Idham a, Noor Aiysah Aris a, b, Nicky Rahmana \\ Putra a, b, Ahmad Hazim Abdul Aziz a, b, Mohd Azizi Che Yunus a, b, * \\ a Centre of Lipids Engineering \& Applied Research (CLEAR), Ibnu Sina Institute for Scientific \& Industrial Research, Universiti Teknologi Malaysia, \\ 81310 UTM Johor Bahru, Johor, Malaysia \\ b Faculty of Chemical \& Energy Engineering, Universiti Teknologi Malaysia, 81310 UTM Johor Bahru, Johor, Malaysia
}

*Corresponding author: azizi@cheme.utm.my

\section{Article history}

Received 28 March 2018

Revised 1 April 2018

Accepted 20 May 2018

Published Online 3 December 2018

\begin{abstract}
Propolis is a resinous substance produced by bees functioned to seal holes, exclude draught, protect against contamination and external intruders inside their hives has been substantially studied and reported to have numerous health properties such as antiseptic, antifungal, antibacterial, antiviral, anti-inflammatory and antioxidant characteristics. Propolis cannot be utilized as raw material, due to its complex mixture of compounds. Hence it must be separated by the extraction process. Extraction targets to removes the inert compounds in the propolis sample and preserves the flavonoids and polyphenolic fraction. The most common technique used in propolis extraction is solvent extraction that involves the use of solvents such as ethanol, water, hexane, ethyl-acetate and chloroform. However, this conventional technique has some drawbacks including strong residual flavour, possible adverse reactions, harmful to the environment, low quality of the extract and long process period requirement. Supercritical carbon dioxide $\left(\mathrm{SC}-\mathrm{CO}_{2}\right)$ is one of the alternative techniques to conventional extraction that was reported to be an excellent method to purify and fractionate bioactive compounds from natural sources. $\mathrm{SC}-\mathrm{CO}_{2}$ extraction was first introduced for analytical application because of the demand to reduce organic solvent utilization in a laboratory environment. It has now become a favourite technique in extraction, fractionation, refinement, and deodorization of natural sample matrices in laboratory scale and industrial scale. Carbon dioxide is an ideal supercritical solvent due to its non-toxic, non-polluting, non-flammable, recoverable and environmentally benign properties. Therefore, this mini review aims to discuss the application of supercritical carbon dioxide extraction specifically on propolis sample starting with a brief introduction on propolis, methods of propolis extraction, the principle of $\mathrm{SC}-\mathrm{CO}_{2}$ extraction, application of $\mathrm{SC}-\mathrm{CO}_{2}$ in propolis extraction, advantages of SC- $\mathrm{CO}_{2}$ extraction and lastly comparison between $\mathrm{SC}-\mathrm{CO}_{2}$ and conventional extraction techniques.
\end{abstract}

Keywords: Supercritical carbon dioxide, propolis, extraction

\section{INTRODUCTION}

Propolis is one of the bee products which has gained the attention of researchers and consumers worldwide recently due to its numerous health benefits. It is a resinous substance collected by bees from exudates of surrounding plants, mixed with their saliva and waxes, gathered to their hive to protect against contamination and invaders, to seal holes, and to maintain the temperature inside the hives. This product consists of $50 \%$ of resins, $30 \%$ of waxes, $10 \%$ of essential oil, $5 \%$ of pollen and $5 \%$ of organic compound and minerals (Almutairi et al., 2014). Propolis has been reported to possess various therapeutic activities, such as antitumoral, antifungal, anticancer, antiinflammatory, antiviral and antibacterial properties (Abu Mellal et la., 2012). For this reason, it has been widely used in pharmacological, food and beverages industry to enhance human health and prevent diseases such as cancer, heart disease, inflammation and diabetes (Chen et al., 2009).

Propolis has been used for centuries as traditional medicine, especially in Europe and Japan (Biscaia \& Ferreira, 2009). Thus, it has become a subject of intense interest in pharmacological and chemical studies for the last 30 years, searching for functional evidence to its diverse advantages. Many studies have proven therapeutic activities of propolis to be attributed to compounds such as flavonoids, phenolic acids, terpenes and sesquiterpenes (Marcucci et al., 2001, Kumazawa et al., 2004, Nagai et al., 2003, Lu et al., 2005).

Even though it consists vital health functional compounds, propolis cannot be used as raw material because it also contains an inert compound - waxes that comprises up to $30 \%$ of its total content (Almutairi et al., 2014). Wax is a complex mixture of organic compounds, predominantly monoesters, formed by moieties of carboxylic acid and alcohol with unbranched carbon chain, followed by hydrocarbons with odd numbers of carbon atom (Custodio et al., 2003). To obtain propolis with a high concentration of functional compounds, it must be purified using extraction process which helps to remove the inert material and preserve the contributing fractions. Solvent extraction with ethanol is the most commonly used method to obtain dewaxed propolis extract with high functional compounds such as flavonoids and polyphenolic content (Pietta, 2000).

Extraction methods are constantly associated with product quality. Extraction techniques that can produce pure extract without solvent residue are considered as good methods (Manirazika et al., 2001). Among well-established conventional extraction methods encompasses hydro-distillation (HD) and organic solvent extraction which includes soxhlet and maceration process (Weinhold et al., 
2008). On the other hand, modern techniques in relation to propolis extraction have been studied by many researchers, for example, ultrasound extraction, microwave-assisted extraction (Pellati et al., 2007), lyophilization, nanofiltration (Tylkowski et al., 2010) and supercritical carbon dioxide extraction (Chen et al., 2009).

Supercritical $\mathrm{CO}_{2}$ extraction is an extraction technique that employs $\mathrm{CO}_{2}$ at its supercritical condition. Above its critical temperature of $31^{\circ} \mathrm{C}$ and critical pressure of $7.38 \mathrm{MPa}$, supercritical $\mathrm{CO}_{2}$ acts as a solvent to separate targeted compounds from their natural matrixes (Herrero et al., 2010). $\mathrm{CO}_{2}$ is recognized as a green solvent due to its non-toxic, non-flammable, non-polluting properties and generally acknowledged to be a safe extracting agent by FDA (Food \& Drug Administration) and EFSA (European Food Safety Authority) (Herrero et al., 2010). Its easily tuned solvent combined with high diffusivity properties makes supercritical $\mathrm{CO}_{2}$ a promising method for solute separation. In addition, analyte recovery for SC$\mathrm{CO}_{2}$ extraction is very simple and it is able to yield solvent-free analytes as the $\mathrm{CO}_{2}$ returns into gaseous form at room condition. This allows extraction to be carried out at low temperatures using a nonoxidant medium which is important for food and natural products sample preparation that often involves thermally liable and easily oxidized compound extracts (Herrero et al., 2010).

To our literature extend, $\mathrm{SC}-\mathrm{CO}_{2}$ technology has been used mainly as a sample preparation technique for the analysis of target compounds from foods and natural product (Engelhardt et al., 1991). It is also used commonly in the process development area, in which target compounds are extracted from different sample matrices. SC$\mathrm{CO}_{2}$ has been regarded as a promising tool not only from a laboratory point of view, but also in the industrial scale (i.e., food and natural products industries) (Fiori, 2010). Several papers have been published in the evaluation of the industrial and economical practicality of some $\mathrm{SC}-\mathrm{CO}_{2}$ developed processes, such as brewery spent grain management (Fernandez et al., 2008) and essential oil extraction from anise, fennel and rosemary (Pereira \& Meireles, 2007). On the other hand, there are wide studies of SC- $\mathrm{CO}_{2}$ application in laboratory scale such as extraction of Lamiaceae herbs (Babovic et al., 2010), Strobilanthes crispus (Pecah Kaca) (Liza et al., 2010), aloe vera (ElShemy et al., 2010), chia seed oil (Ixtaina et al., 2010), microalgae (Dejoye et al., 2011) and many more.

Vast application and benefits of this assuring $\mathrm{SC}-\mathrm{CO}_{2}$ technique have drawn current researchers to investigate the application of this process in propolis extraction. $\mathrm{SC}-\mathrm{CO}_{2}$ appears to be an ideal solvent to extract bioactive compounds identified in propolis such as flavonoids and phenolic acids including p-coumaric acid, ferulic acid, cinnamic acids, pinobaskin, kaempferol, artepillin $\mathrm{C}$, and others (Lee et al.,2007; Catchpole et al., 2004). A clear positive trend in propolis extraction using $\mathrm{SC}-\mathrm{CO}_{2}$ technique is shown by several successful studies (Chen et al., 2009; Lee et al.,2007; Catchpole et al., 2004).

In recent available literature, the chemical, biological, and nutritional aspects of propolis as a source of functional compounds, as well as technological aspects of the $\mathrm{SC}-\mathrm{CO}_{2}$ extraction have been reviewed. However, to date, there's no reference available for a specific review of the application of $\mathrm{SC}-\mathrm{CO}_{2}$ in propolis extraction. Hence, the intention of this mini review is to summarize the findings related to propolis extraction with an emphasis on using $\mathrm{SC}-\mathrm{CO}_{2}$ technology and related matter.

\section{PROPOLIS}

Propolis or sometimes also known as 'bee glue' is defined by the United States Department of Agriculture, USDA as 'a gum that is gathered by bees from various plants. It may vary in colour from light yellow to dark brown. It may cause staining of the comb or frame and may be found in extracted honey' (USDA, 1985). The word propolis was developed from a Greek name in which 'pro' is meant by 'police' and 'polis' is meant by 'city' that describe one of their function is to protect the entrance of beehives against intruders.

The precise composition of raw propolis could vary among different places and source. It is been reported that propolis contains more than 160 constituents and varies significantly because of their different botanical and geographical sources (Choi et al., 2006). These constituents include polyphenols (flavonoids, phenolic acids and their ester, phenolic aldehydes, alcohol and ketones), amino acids, steroids, coumarins, sesquiterpene quinones and inorganic compounds. Due to this variation in their chemical compositions, it seems to be challenging to identify and standardized propolis profile from different places worldwide (Choi et al., 2006).

The range of pharmacological activities by propolis sample such as antioxidant, antibacterial, antifungal and anti-inflammatory have been attributed to the presence of bioactive compounds. In addition, other pharmacological properties that have also been associated with propolis are immunomodulatory, hematostimulative, hepatoprotective, and cytotoxic activities.

The study by Funakoshi-Tago et al., (2016) found that five types of flavonoids; isoliquiritigenin, chrysin, 3',4'-dihydroxy-4methoxydalbergione, 4-methoxydalbergion, and cearoin was present in Nepalese propolis. These flavonoids have markedly inhibited inflammatory responses in iNOS (inducible nitric oxide synthase), $\mathrm{TNF} \alpha$ (tumour necrosis factor) and CCL2 (monocyte chemoattractant protein-1) mRNA expression. They concluded that propolis's inhibitory effects on inflammatory responses were significantly correlated with the intensities of these five types of flavonoids.

Presence of formononetin, isoliquiritigenin, (3S)-neovestitol, and (3S)-vestitol were suggested to be responsible for antibacterial activity against Streptococcus mutans, Streptococcus sobrinus, Staphylococcus aureus and Actinomyces naeslundii in Brazilian propolis (Bueno-Silva et al., 2017). Meanwhile, luteolin and quercetin compound in Brazilian red propolis have been reported to be associated with antibacterial activity against Escherichia coli, Pseudomonas aeruginosa and Staphylococcus aureus (Regueira et al., 2017).

The most commonly known therapeutic properties of propolis was its antioxidant ability which is contributed by the phenolic compounds, particularly phenolic acids and their esters (Socha et al., 2015). Phenolic compounds inhibit the free radical reactions, capturing the superoxide amino radicals and peroxy radicals, reducing transition metal ions and inhibits the formation of reactive oxygen species (Socha et al., 2015). P-coumaric acid and ferulic acid were the dominant phenolic acid found in Poland propolis, whereas, chrysine and galangine were dominant flavonoids found in the same sample. Socha et al., (2015) observed a significant linear correlation between these phenolic compounds with antioxidant activity and reducing power as measured by DPPH (free radical diphenylpicrylhydrazyl) and FRAP (ferric reducing ability of plasma) assay respectively.

\section{METHODS OF PROPOLIS EXTRACTION}

Currently, there are two categories of extraction technique which are conventional and modern extraction method. Example of modern extraction methods includes supercritical fluid extraction (SFE), ultrasound-assisted extraction (UAE), microwave-assisted extraction (MAE), pressurized liquid extraction (PLE), and pressurized hot water extraction (PHWE) developed an alternative to conventional extraction method. The conventional extraction method of solid-liquid extraction (SLE) involves solvent application and leaching process which encompasses soxhlet extraction (SE), percolation and maceration extraction (ME) (Socha et al., 2015).

Up until now, several conventional extraction methods such as the ones listed above have been employed in the extraction of bioactive compounds in propolis sample. Conventional extraction methods generally require a huge amount of solvents and it is time-consuming and complicated. Hence, there is a need to develop and establish a greener extraction method with higher efficiency in enriching bioactive compounds from propolis sample. In that regard, a number of researchers had investigated and improved these conventional propolis extraction technique by introducing a new distinct propolis extraction technique.

Machado et al., (2016) had compared Brazilian propolis extract obtained by conventional extraction technique - ethanolic extraction $(\mathrm{EtOH})$ with modern extraction technique - supercritical $\mathrm{CO}_{2}$ 
extraction. They found a higher concentration of Artepillin $\mathrm{C}$ and $\mathrm{p}$ coumaric acid in propolis extract obtained by supercritical $\mathrm{CO}_{2}$ extraction at $50^{\circ} \mathrm{C}, 350 \mathrm{bar}$, and $1 \%$ of ethanol addition as co-solvent as compared to conventional ethanolic extraction. Supercritical $\mathrm{CO}_{2}$ has a higher selectivity for extraction of these target compounds which were particularly related to antioxidant activities (DPPH \& ABTS) and antibacterial activities of the propolis extract.

Microwave-assisted extraction (MAE) is one of the modern extraction techniques which can reduce extraction time significantly by allowing rapid and homogenous distribution of energy throughout the solid matrix and solvent (Hamzah \& Leo, 2015). A large amount of energy, in the form of heat, is utilized for extraction by microwaves. Moisture in the solid matrix adsorbs microwave energy and creates internal superheating that promotes the solid disruption, thus improving the recovery of bioactive compounds in a short duration (Destandau et al., 2013). Propolis extraction using MAE can be accomplished in a shorter time with less solvent degradation and without severe compound degradation as compared to conventional extraction method such as maceration (Hamzah \& Leo, 2015). MAE carried out at $2 \times 10$ seconds of microwave irradiation exposure to the propolis sample resulted in $73 \%$ of extract yield. Meanwhile, maceration extraction had only resulted in $58 \%$ of extract yield after 72 hours of extraction period.

On the other hand, ultrasonic extraction had also been mentioned as a fast and efficient extraction method for propolis. Acoustic cavitation by ultrasonic energy inside the sample matrix allowed rapid extraction of bioactive compounds. This technology showed great potential in reducing extraction time and increased extraction yield. Ultrasonic extraction gave a higher percentage of phenolic compounds extracts than MAE. Ultrasonic extraction had resulted in total phenolic of $50 \%$ after $30 \mathrm{~min}$ extraction period, whilst, MAE had resulted in $40 \%$ of total phenolic after $2 \times 10$ s of microwave irradiation exposure to the propolis sample. In addition, this method provided less operating hours and less labour (Trusheva et al., 2007).

Application of membrane concentration process or specifically nanofiltration in propolis extraction has been growing because of several benefits, such as low energy consumption, the absence of phase transition, and operation at low temperature. This technique is based on the principle of solute selective permeation through semipermeable, inorganic or polymeric membranes. Mechanical pressure is used as the driving force for mass transfer across the membrane for most membrane processes, such as reverse osmosis, nanofiltration, ultrafiltration and microfiltration. Nanofiltration process reported having high efficiency in extraction and concentration of phenolic and flavonoids compounds up to $90 \%$ in aqueous and ethanolic propolis solution (Mello et al., 2010). Nanofiltration process had concentrated flavanoids compounds, $71.93 \mathrm{mg} / \mathrm{g}$ and phenolic compounds, 105.08 $\mathrm{mg} / \mathrm{g}$ in ethanolic solution of propolis sample. Meanwhile, the same process had concentrated flavanoids compounds, $96.76 \mathrm{mg} / \mathrm{g}$ and phenolic compounds, $104.74 \mathrm{mg} / \mathrm{g}$ from an aqueous solution of the propolis sample.

Pressurized liquid extraction (PLE) is becoming an important sample preparation technique in food analysis and its application in the extraction process including propolis extraction process. It requires less solvent, favourable for environmental aspect and allows efficient analytes extraction in an inert and closed environment, thus enabling high-temperature extraction. Parameters such as temperature, pressure, solvent type, extraction time and cell size were stated to affect the performance of propolis extraction significantly. Study by Erdogan et al., (2011) had mentioned that $40^{\circ} \mathrm{C}, 1500$ psi, Ethanol:water:hydrochloric acid; (70:25:5, v/v/v) containing $0.1 \%$ tert-butylhydroquinone (tBHQ) as solvent, three extraction cycles within $15 \mathrm{~min}$, and a cell size of $11 \mathrm{~mL}$ was the most favorable PLE operating conditions for propolis extraction. A recovery rate ranging from $97-99 \%$ of polyphenol compounds in propolis which encompasses gallocatechin (GCT), catechin (CT), epicatechin, gallate (ECTG), caffeic acid (CA), chlorogenic acid (ChA), and myricetin (Myr), can be extracted by PLE (Erdogan et al., 2011).

Table 1 listed details of different extraction methods in propolis extraction encompass the propolis source, solvent, specific method, condition used and their results.
Table 1 List of different extraction methods of propolis extracts.

\begin{tabular}{|c|c|c|c|c|c|}
\hline $\begin{array}{l}\text { Propolis } \\
\text { Source }\end{array}$ & Solvent & Method & Condition & Results & Authors \\
\hline Brazil & $\begin{array}{c}\text { Water } \\
\text { Ethanol }\end{array}$ & Nanofiltration & $\begin{array}{l}\text { NF90 } \\
\text { membrane } \\
\mathrm{T}-20^{\circ} \mathrm{C} \\
\mathrm{P}-6.0 \text { bar } \\
\mathrm{t}-30 \mathrm{~min}\end{array}$ & 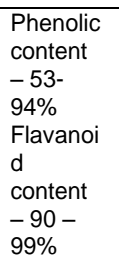 & $\begin{array}{l}\text { Mello et } \\
\text { al., } \\
(2010)\end{array}$ \\
\hline Italy & $\begin{array}{c}\text { Ethanol } \\
\text { Ethyl } \\
\text { acetate } \\
\text { Water } \\
\mathrm{HCl} \\
\text { Methanol } \\
\text { Acetone }\end{array}$ & $\begin{array}{l}\text { Pressurized } \\
\text { liquid } \\
\text { extraction }\end{array}$ & $\begin{array}{l}\mathrm{T}- \\
20,40,60,80 \\
{ }^{\circ} \mathrm{C} \\
\mathrm{P}-500, \\
1000,1500, \\
2000 \mathrm{psi} \\
\mathrm{t}-15,30, \\
40,60,90, \\
120 \mathrm{~min} \\
\text { cell size - } \\
11.22 \mathrm{ml}\end{array}$ & $\begin{array}{l}\text { Optimu } \\
\mathrm{m} \\
\text { condition } \\
-40^{\circ} \mathrm{C}, \\
1500 \\
\mathrm{psi}, 15 \\
\text { min, } \\
11 \mathrm{ml} \text { cell } \\
\text { size }\end{array}$ & $\begin{array}{l}\text { Erdogan } \\
\text { et al. } \\
\text { (2011) }\end{array}$ \\
\hline Bulgaria & Ethanol & $\begin{array}{l}\text { Maceration } \\
\text { extraction }\end{array}$ & $\begin{array}{l}\text { Propolis: } \\
\text { solvent ratio } \\
-1: 20 \\
t-72 \text { hours }\end{array}$ & $\begin{array}{l}\text { Phenolic } \\
\text { content } \\
-44 \% \\
\text { Flavanoi } \\
d \\
\text { content } \\
-30 \% \\
\text { Total } \\
\text { extract } \\
\text { yield - } \\
58 \%\end{array}$ & $\begin{array}{l}\text { Trushev } \\
\text { a et al. } \\
(2007)\end{array}$ \\
\hline Thailand & Ethanol & $\begin{array}{l}\text { Ultrasonic } \\
\text { extraction }\end{array}$ & $\begin{array}{l}t-15,30 \\
45,60 \mathrm{~min}\end{array}$ & $\begin{array}{l}\text { Optimu } \\
\text { m } \\
\text { inhibitory } \\
\text { effects - } \\
15 \& 30 \\
\text { min }\end{array}$ & $\begin{array}{l}\text { Sanpa } \\
\text { et al. } \\
\text { (2012) }\end{array}$ \\
\hline Italy & $\begin{array}{l}\text { Ethanol } \\
\text { Water }\end{array}$ & $\begin{array}{l}\text { Microwave- } \\
\text { assisted } \\
\text { extraction }\end{array}$ & $\begin{array}{l}\text { Power - } \\
300 \mathrm{~W} \\
\text { Frequency } \\
-2450 \mathrm{MHz} \\
\text { EtOH: } \\
\text { solvent ratio } \\
-80: 20 \mathrm{v} / \mathrm{v} \\
\mathrm{T}-106^{\circ} \mathrm{C}\end{array}$ & $\begin{array}{l}\text { Phenolic } \\
\text { content } \\
-5- \\
120.8 \\
\mathrm{mg} / \mathrm{g} \\
\text { Flavanoi } \\
\mathrm{d} \\
\text { content } \\
-2.5- \\
168.0 \\
\mathrm{ma} / \mathrm{a}\end{array}$ & $\begin{array}{l}\text { Pellati et } \\
\text { al., } \\
(2013)\end{array}$ \\
\hline Brazil & Ethanol & $\begin{array}{l}\text { Supercritical } \\
\mathrm{CO}_{2} \\
\text { extraction }\end{array}$ & $\begin{array}{l}1 \% \mathrm{EtOH} \\
\mathrm{P}-350 \text { bar } \\
\mathrm{T}-50^{\circ} \mathrm{C} \\
\mathrm{CO}_{2} \text { flow } \\
\text { rate }- \\
6 \mathrm{~g} / \mathrm{min} \\
\mathrm{t}-2 \text { hours } \\
30 \text { min }\end{array}$ & $\begin{array}{l}\text { Phenolic } \\
\text { content } \\
-157.43 \\
\mathrm{mg} / \mathrm{g} \\
\text { Flavanoi } \\
\mathrm{d} \\
\text { content } \\
-25.46 \\
\mathrm{mg} / \mathrm{g} \\
\mathrm{DPPH}- \\
116.49 \\
\text { IC50 } \\
\text { ABTS-- } \\
87.60 \%\end{array}$ & $\begin{array}{l}\text { Machad } \\
\text { o et al., } \\
\text { (2016) }\end{array}$ \\
\hline
\end{tabular}

Hot-pressurized water (HPW) technique is another modern extraction method that has been applied to extract bioactive compounds in propolis sample. This technique is based on the principle of water that has dielectric properties, viscosity, and surface tension that is close to organic solvents while offering more advantages compared to conventional organic solvent extraction. A study by Chen et al., (2007) found seven flavonoids, caffeic acid phenethyl ester and four phenolic acids compounds obtained from HPW extraction were $36 \%$ higher than that from hot water extraction at atmospheric pressure. Additionally, the addition of natural surfactant in the process had increased the mentioned compounds extraction to $44 \%$ higher as compared to without the addition of natural surfactant. This extract was also reported to have successfully suppressed the growth of leukemia, lung cancer and liver cancer cells (Chen et al., 2007). 


\section{PRINCIPLE OF SC-CO 2 EXTRACTION}

A supercritical fluid has been applied in the extraction of the natural product since the end of the 1970s. However, for a long period, the applications have been limited only to a few products. Currently, the growth and improvement of supercritical fluid equipment's as well as the processes have begun to pay off and gain much interest from the industries (Herrero et al., 2010). This interest is demonstrated by numerous recent scientific papers regarding the SFE technique. Furthermore, SFE application in industries has been growing tremendously, indicated by patents since the early $1990 \mathrm{~s}$ (Herrero et al., 2010). Figure 1 illustrated a schematic diagram of the $\mathrm{SC}-\mathrm{CO}_{2}$ extraction process.

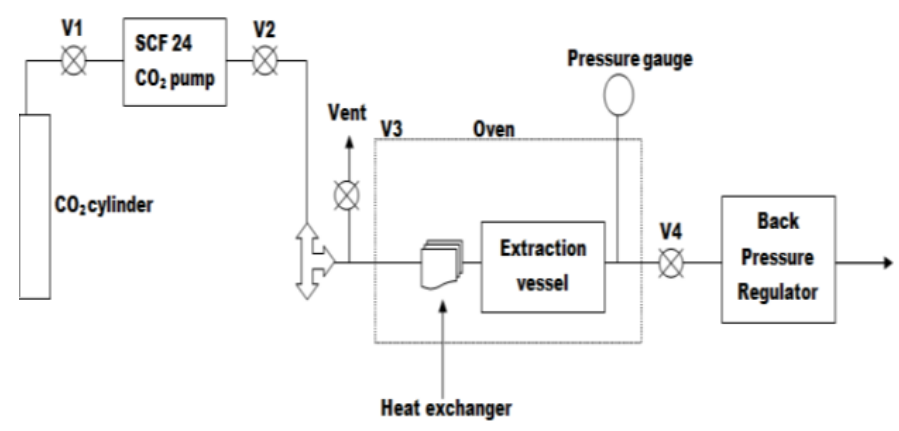

Figure 1 Schematic diagram of $\mathrm{SC}-\mathrm{CO}_{2}$ extraction.

Supercritical fluid extraction is one of the methods used in recovering bioactive compound from natural sources that have shown to be more advantageous and is more environmental friendly compared to conventional extraction methods. SFE technique appears to be a good extraction and fractionation process for industrial application, especially in pharmaceutical and food industries (Lang \& Wai, 2001). Each fluid is identified by its critical point, which is described by its critical temperature and critical pressure. This fluid cannot be further liquefied above its critical temperature, despite any pressure applied, however, it may reach the density closer to the liquid state. A substance above its critical temperature and critical pressure is considered as a supercritical fluid. Supercritical fluid is a phase where a distinct gas and liquid phase does not exist (McHugh \& Krukonis, 2013). Figure 2 below showed a pressure-temperature diagram of the supercritical fluid.

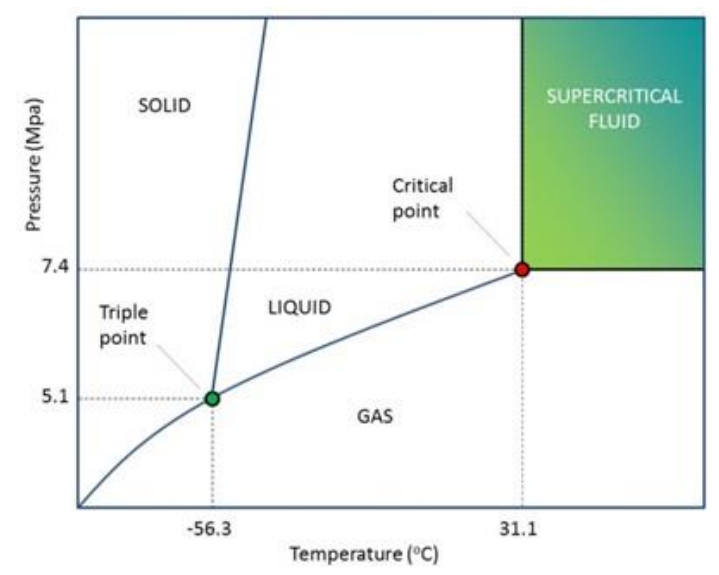

Figure 2 Pressure-temperature diagram.

High density provides better compound solubilization by $\mathrm{SC}-\mathrm{CO}_{2}$, whilst low viscosity allows easier solid penetration and enables less friction flow. Solvating strength of $\mathrm{SC}-\mathrm{CO}_{2}$ could be manipulated by adjusting its operating parameters, mainly temperature and pressure (Kalani \& Yunus, 2011). Adjusting the critical temperature and critical pressure can alter $\mathrm{SC}-\mathrm{CO}_{2}$ properties and enhance its efficiency to penetrate and subsequently extract targeted bioactive compound from the natural source. In addition, $\mathrm{SC}-\mathrm{CO}_{2}$ is mentioned to be an excellent solvent to recover the high amount of lipid-soluble compounds (Sahena et al., 2009).

$\mathrm{SC}-\mathrm{CO}_{2}$ extraction parameters comprising extraction temperature, pressure, modifier, flow rate, process time, moisture content, and sample particle size has significant relation with extraction product quantitatively and qualitatively (Zuknik et al., 2012). Temperature as one of the important parameters in the $\mathrm{SC}-\mathrm{CO}_{2}$ process could significantly affect the extraction yield. This had been reported by Favati et al. (1991), with an increase in temperature from $40{ }^{\circ} \mathrm{C}$ to 50 ${ }^{\circ} \mathrm{C}$ at $20 \mathrm{MPa}$, the evening primrose oil yield dropped from $66.1 \%$ to $59.6 \%$ with a further drop to $31.4 \%$ at $60{ }^{\circ} \mathrm{C}$. Meanwhile, they also found that the oil yield increased from $96.8 \%$ to $97.5 \%$ with increasing temperature from $40{ }^{\circ} \mathrm{C}$ to $50^{\circ} \mathrm{C}$ and then slightly dropped to $97.2 \%$ at $60{ }^{\circ} \mathrm{C}$. Increase in process temperature will increase the vapour pressure of the solute and reduce the possibility of mass transfer resistance between solute and the sample's matrix to happen.

On the other hand, process pressure could also affect the extraction yield. An increase in process pressure does increase the extraction yield due to an increase in solvent density that enhances the solvating power of $\mathrm{SC}-\mathrm{CO}_{2}$ solvent and risen the intermolecular interaction with the solutes. This phenomenon eases the dissolution of solutes and solvent, thus improving the extraction yield obtained (Machmudah et al., 2006). This has been reported by Tai \& Kim (2014) where they found an increase of Gac oil recovery from $72.3 \%$ to $91.4 \%$ at an increase of pressure from 200 to 400 bar, with constant temperature $323 \mathrm{~K}$ and flow rate $70 \mathrm{kgh}-1 \mathrm{~kg}-1$.

In addition, the $\mathrm{SC}-\mathrm{CO}_{2}$ flow rate has also a strong influence on the extraction yield obtained. The optimum $\mathrm{SC}-\mathrm{CO}_{2}$ flow rate must be sufficient for solvent-solute saturation. Unsaturated $\mathrm{SC}-\mathrm{CO}_{2}$ could exit the extractor at lower flow rate due to mass transfer resistance that limits the amount of solute transported in the solvent. Meanwhile, as an increase of flow rates, the mass transfer resistance will be reduced until the exiting solvent is saturated and thus equilibrium is achieved and the maximum yield can be attained (Kumoro \& Hasan, 2007). SC- $\mathrm{CO}_{2}$ extraction of flaxseed oil had shown that at a lower flow rate of $1 \mathrm{~L} / \mathrm{min}$ required a longer extraction time to reach the maximum extraction yield, whilst the maximum extraction yield had increased at a higher flow rate of $3 \mathrm{~L} / \mathrm{min}$ from $66 \%$ to $74 \%$ (Bozan \& Temelli, 2002).

To summarize advantages of $\mathrm{SC}-\mathrm{CO}_{2}$, i) it can dissolve non-polar to slightly polar compounds, ii) possess high solvating power towards low molecular weight compounds that decreases with bigger molecular weight compounds, iii) high affinity towards medium molecular weight oxygenated organic compounds, iv) low solubility towards water at temperature below $100^{\circ} \mathrm{C}$, v) insoluble with protein, polysaccharides, sugars and mineral salts, and vi) is capable of isolating less volatile, higher molecular weight, more polar compounds as the pressure increases.

The main disadvantage of $\mathrm{SC}-\mathrm{CO}_{2}$ is its low polarity, which reduces the efficiency to extract polar compound in the natural sample. However, this drawback can be overcome by applying polar modifier (co-solvent) to alter the $\mathrm{SC}-\mathrm{CO}_{2}$ polarity and help to increase its solvating power towards targeted polar compounds (Herrero et al., 2006). For instance, application of methanol in a small percentage (1$10 \%)$ to $\mathrm{CO}_{2}$ could extend $\mathrm{SC}-\mathrm{CO}_{2}$ extraction range to extract more polar compounds (Herrero et al., 2006). The co-solvent can also reduce the interaction between polar compounds and its matrix, thus improving quality of the extract product.

The design of $\mathrm{SC}-\mathrm{CO}_{2}$ process is highly dependent on the scenario of equilibrium phase which is strongly sensitive to operating parameters and condition changes. Thus, equilibrium phase plays a significant role in the $\mathrm{SC}-\mathrm{CO}_{2}$ extraction process.

One of the vital areas of concern in $\mathrm{SC}-\mathrm{CO}_{2}$ extraction processes is extraction optimization. The adjustment to obtain optimum values for different variables attributing to $\mathrm{SC}-\mathrm{CO}_{2}$ extraction process could significantly increase extraction yield recovery, as well as the concentration of the targeted compound. The main optimization of $\mathrm{SC}-\mathrm{CO}_{2}$ extraction process involves finding its optimum operating parameters. Response surface methodology (RSM) is one of the favoured methods in optimization process of $\mathrm{SC}-\mathrm{CO}_{2}$ extraction. 
Simultaneous optimization of different variables could be done by using RSM. Two variables that could be set as response variables are extraction yield and concentration of targeted compounds. RSM requires more experimental points to provides more information on how the extraction is working. Many researchers had studied optimization of $\mathrm{SC}-\mathrm{CO}_{2}$ extraction process of various natural products employing RSM such as extraction of swietenia mahagoni seed (Hartati et al., 2016), palm oil mesocarp (Yunus et al., 2015), jatropha curcasl seed (Azizi \& Ismail, 2008), piper betel linn leaves (Aziz et al., 2016) and castor oil (Danlami et al., 2015).

\section{APPLICATION SC-CO 2 IN PROPOLIS EXTRACTION}

Supercritical carbon dioxide extraction of propolis yielded an extractant that has been proven to possess better biological activities as compared to conventional organic solvent extraction. Vast researches had been carried out to investigate $\mathrm{SC}-\mathrm{CO}_{2}$ extraction on propolis sample from different origin worldwide. It has been reported that the optimum operating parameters to remove wax and extract rich fat-soluble flavonoids was at a pressure of $600 \mathrm{bar}$ and temperature of 313K (Catchpole et al., 2004). Application of co-solvent, for instance, ethanol and water, in $\mathrm{SC}-\mathrm{CO}_{2}$ extraction of Brazilian and Taiwanese propolis have significantly enhanced water solubility and anti-cancer activity of the product (Wu et al., 2009). A patent had also described $\mathrm{SC}-\mathrm{CO}_{2}$ extraction of propolis sample with the addition of co-solvent yielded different classes of bioactive compounds at increasing extraction pressure (Wu \& Luyu, 2000). Propolis extract obtained from $\mathrm{SC}-\mathrm{CO}_{2}$ extraction are sold as commercial products in Japan, specifically marketed for their anticancer properties. In other approaches, a fine particle consisting concentrated bioactive compounds from propolis extract could be produced through $\mathrm{SC}-\mathrm{CO}_{2}$ anti-solvent precipitation technique (Wu et al., 2009). Furthermore, $\mathrm{SC}-\mathrm{CO}_{2}$ extraction technique had also been used in the fractionation of propolis sample mixture, and at the same time in the fractionation of lecithin with triglyceride oil, curcuminoid with triglyceride oil and essential oil with triglyceride oil mixtures (Teberikler et al., 2001).

Several bioactive compounds in propolis, such as flavonoids and cinnamic acid derivatives are categorized as a polar compound, hence they have minimal to zero solubility in $\mathrm{SC}-\mathrm{CO}_{2}$. Therefore, incorporating a modifier or co-solvent in $\mathrm{SC}_{-} \mathrm{CO}_{2}$ extraction could help increase solubility strength between solvent and solute, thus improving the extraction efficiency. $\mathrm{CO}_{2}$ alone and $\mathrm{CO}_{2}$ with water were mentioned to be less effective for dissolving flavonoid compounds, whilst $\mathrm{CO}_{2}$ with ethanol was observed as a more effective solvent (Catchpole et al., 2004). Non-polar flavonoid derivatives, flavone, and 3-hydroxyflavone, were measured to be soluble in $\mathrm{CO}_{2}$ in range of $10^{-5}$ to $10^{-4}$ mole fraction (Catchpole et al., 2004).

Amount of flavonoids had increased in water-soluble propolis extracted by the SC-CO ${ }_{2}$ process as reported by You et al., (2002). Antioxidant compounds from propolis were favourably extracted using $\mathrm{SC}-\mathrm{CO}_{2}$ fractionation technique (Wang et al., 2004). Ethylacetate was used as a modifier in $\mathrm{SC}-\mathrm{CO}_{2}$ extraction of Brazilian propolis and has obtained an anti-cancer associated compound, DHCA (Lee et al., 2007). 3,5-diprenyl-4-hydroxycinnamic acid, DHCA, also known as Artepillin $\mathrm{C}$ found in Brazilian propolis, exhibited anti-cancer properties by inhibiting effects of renal carcinogenesis through its oxy-radical scavenging characteristic (Ahn et al., 2007). Concurrently, Chen et al., (2009) reported that $\mathrm{SC}-\mathrm{CO}_{2}$ extract from Brazilian propolis contained 95\% wt DHCA that can inhibit the growth of colon cancer and human leukemia (HL-60) effectively.

$\mathrm{SC}-\mathrm{CO}_{2}$ extraction steps could be adjusted so that the process temperature and pressure are set in sequential steps. Through this approach, a different fraction of compounds can be extracted from one raw material as the supercritical fluid is at its moderate density which separates highly soluble components such as essential oil. Meanwhile, heavier substances such as antioxidant compounds are separated by the fluid which becomes a higher density compounds towards the end of the process. A mixture of Brazilian propolis extract had been fractionated using this technique and yielded a high concentration of interest compound in one fraction, with higher selectivity at a low solvent density (Paviani et al., 2010).

Considering the good relevance of SC- $\mathrm{CO}_{2}$ extraction technology as an alternative method for propolis extraction, in addition to promising and important health compounds present in propolis source, there is a need for more investigation regarding this subject. Recently, demand to establish a good and optimum condition for $\mathrm{SC}-\mathrm{CO}_{2}$ extraction of propolis extraction has increased among researchers (Revercon \& De Marco, 2006). However, application of this technique was only slightly explored. Listed in Table 2 are all available literature reported on the extraction of propolis sample using SC- $\mathrm{CO}_{2}$ technology until 2017, hence, this may be used as a reference for future investigation and improvement.

\section{ADVANTAGES OF SC-CO 2 EXTRACTION}

Raventos et al., (2002) had summarized advantages of SC-CO2 extraction as follow; i) good quality and better purity of recovered product, ii) faster extraction and separation process, iii) extract are free from solvent residue, iv) able to fractionate specifically targeted compounds and v) low in production cost. Recently, direct applications of high-value product in pharmaceutical and food industries have demanded interest in extraction and fractionation of bioactive compounds from plant and animal sources. Awareness of the health, environmental and safety hazards related to the application of organic solvents and possible solvent contamination in food processing's final products among the public had risen. The need to search for excellent extraction techniques to recover natural bioactive health beneficial compounds in various natural material is increasing. The urgent needs for development and improvement of new separation technologies in food processing industries are contributed by the high cost of organic solvents, stricter environmental regulations and new requirement for ultra-pure and high value-added products in this area (Mohamed \& Mansoori, 2002). Conventional extraction techniques can cause the destruction of valuable compounds due to the high-temperature application (Chemat \& Khan, 2011). Moreover, the usage of organic solvents may also produce an extract with solvent residue, hence reducing the product quality.

SC- $\mathrm{CO}_{2}$ has several vital properties which are regarded as a promising alternative technology to current conventional solvent extraction methods. For example, $\mathrm{SC}-\mathrm{CO}_{2}$ have lower viscosity and higher diffusivity as compare to liquid solvents, hence they can penetrate porous solid material better, resulting in faster extraction due to much faster mass transfer. In addition to comparable and better recoveries in $\mathrm{SC}-\mathrm{CO}_{2}$ extraction, the process time could also be reduced to only a few minutes as compared to hours and days in conventional liquid-solid extraction. The continuous flow of $\mathrm{SC}-\mathrm{CO}_{2}$ through the sample in this extraction process provides complete or quantitative extraction. Solvation power of $\mathrm{SC}-\mathrm{CO}_{2}$ can also be manipulated by adjusting their pressure and temperature which leads to a remarkably high selectivity. This advantage of tunable solvation power is specifically beneficial to the extraction of complex samples, such as plant material. For example, selective extraction of vindoline compounds from among other 100 alkaloid components from Catharanthus roseus leaves (Song et al., 1992). Moreover, the extracted solutes dissolved in $\mathrm{SC}-\mathrm{CO}_{2}$ can be easily recovered by the depressurization process, which has replaced the time-consuming sample concentration process. The latter process often results in loss of targeted volatile compounds.

$\mathrm{SC}-\mathrm{CO}_{2}$ extraction method also requires only a little sample consumption, as small as $0.5-1.5$ gram, as compared to conventional methods which need a bigger amount of sample up to $20-100$ grams. It has been reported that more than 100 volatile and semi-volatile compounds could be extracted from only 1.5 gram of fresh plant sample as detected by GCMS, in which each of the components was sufficient for accurate quantifications (Lee \& Markides, 1990). Furthermore, there is no application of environmentally harmful solvent in $\mathrm{SC}-\mathrm{CO}_{2}$ extraction process while tens to hundreds of millilitres of organic solvents may be used in the conventional extraction process. 
Idrus et al. / Malaysian Journal of Fundamental and Applied Sciences Vol. 14, No. 4 (2018) 387-396

Table 2 Summary of studies on the application of $\mathrm{SC}-\mathrm{CO}_{2}$ in propolis extraction. Where, $\mathrm{T}$ - temperature; $\mathrm{P}$ - Pressure; $\mathrm{FR}$ - Flow rate; $\mathrm{SC}-\mathrm{co}-\mathrm{solvent}$ concentration; $\mathrm{t}-$ time

\begin{tabular}{|c|c|c|c|c|c|}
\hline $\begin{array}{l}\text { Propolis } \\
\text { source }\end{array}$ & Pre-treatment & Solvent & $\mathrm{SC}-\mathrm{CO}_{2}$ condition & Results & Authors \\
\hline Brazil & No & Ethyl-acetate & $\begin{array}{l}T-40,50,60^{\circ} \mathrm{C} \\
\mathrm{P}-13891-27681 \mathrm{kPa} \\
\mathrm{FR}-4 \mathrm{~L} / \mathrm{min} \\
\mathrm{SC}-2,4,6 \%\end{array}$ & $\mathrm{SCCO}_{2}$ extract at $50^{\circ} \mathrm{C} \& 4 \% \mathrm{SC}$ resulted in DHCA conc. $13.9 \%$ & Lee et al., (2007) \\
\hline New Zealand & $\begin{array}{l}\text { Yes } \\
{ }^{\star} \text { Ethanol } \\
{ }^{*} \text { Water }\end{array}$ & Ethanol & $\begin{array}{l}T-333 \mathrm{~K} \\
P-250-300 \mathrm{bar} \\
\text { FR ratio }-0.05 \\
\text { SC }-10 \%\end{array}$ & $\mathrm{SCCO}_{2}$ extract resulted in flavonoid content $-20-35 \%$ & Catchpole et al., (2004) \\
\hline Brazil & $\begin{array}{l}\text { Yes } \\
{ }^{*} \text { Ethyl-acetate }\end{array}$ & $\begin{array}{l}\text { Ethyl acetate } \\
\text { Ethanol }\end{array}$ & $\begin{array}{l}\mathrm{T}-308-328 \mathrm{~K} \\
\mathrm{P}-10-20 \mathrm{MPa} \\
\mathrm{FR}-10.8-32.6 \mathrm{~g} / \mathrm{min}\end{array}$ & $\begin{array}{l}\mathrm{SCCO}_{2} \text { extract at } 20 \mathrm{MPa} \& 328 \mathrm{~K} \text { resulted in DHCA conc. } 300 \mathrm{mg} / \mathrm{g} \\
\text { Soxhlet ext }-204 \mathrm{mg} / \mathrm{g}\end{array}$ & Chen et al., (2009) \\
\hline Brazil & No & Ethanol & $\begin{array}{l}T-30,40,50^{\circ} \mathrm{C} \\
P-100-250 \text { bar } \\
\text { FR }-3,5 \mathrm{~g} / \mathrm{min} \\
\mathrm{SC}-2,5,7 \%\end{array}$ & $\begin{array}{l}\mathrm{SCCO}_{2} \text { extract }- \text { total yield } 24.8 \% \\
\text { Soxhlet extract }-73 \%\end{array}$ & Biscaia \& Ferreira, (2009) \\
\hline Italian & No & No & $\begin{array}{l}T-35,40,45^{\circ} \mathrm{C} \\
\mathrm{P}-130,200,270 \mathrm{bar} \\
\mathrm{FR}-2 \mathrm{~L} / \mathrm{min} \\
\mathrm{t}-2.5,4,5.5 \mathrm{~h}\end{array}$ & $\begin{array}{l}\mathrm{SCCO}_{2} \text { extract at } 317 \mathrm{bar}, 45^{\circ} \mathrm{C}, 6.5 \mathrm{hrs}, 2 \mathrm{~L} / \mathrm{min} \mathrm{CO}_{2} \mathrm{FR} \text { resulted in total } \\
\text { yield } 14.3 \%\end{array}$ & De Zordi et al., (2014) \\
\hline Brazil & Yes & No & $\begin{array}{l}\mathrm{T}-328 \mathrm{~K} \\
\mathrm{P}-20 \mathrm{MPa} \\
\mathrm{FR}-10,15,20 \mathrm{~L} / \mathrm{min}\end{array}$ & $\begin{array}{l}\mathrm{SCCO}_{2} \text { extract concentration } 25-250 \mathrm{mg} / \mathrm{ml} \text { - inhibit human colon \& } \\
\text { breast cancer }\end{array}$ & Wu et al., (2009) \\
\hline Brazil & No & Ethyl-acetate & $\begin{array}{l}\mathrm{T}-308-333 \mathrm{~K} \\
\mathrm{P}-13.8-27.6 \mathrm{MPa} \\
\mathrm{FR}-10 \mathrm{~L} / \mathrm{min} \\
\mathrm{SC}-0-6 \%\end{array}$ & $\begin{array}{l}\mathrm{SCCO}_{2} \text { extract at } 20.7 \mathrm{MPa}, 323 \mathrm{~K}, 6 \mathrm{wt} \% \text { ethyl acetate resulted in DHCA } \\
\text { conc. } 41.2 \mathrm{wt} \% \\
\text { Soxhlet extract resulted in DHCA conc. } 91.8 \mathrm{wt} \%\end{array}$ & Chen et al., (2007) \\
\hline Brazil & $\begin{array}{l}\text { Yes } \\
{ }^{*} \text { Ethanol }\end{array}$ & Ethanol & $\begin{array}{l}T-20,35,50^{\circ} \mathrm{C} \\
P-150,200,250 \mathrm{bar} \\
\mathrm{FR}-1 \mathrm{~g} / \mathrm{min} \\
\mathrm{SC}-0,5,10,15 \%\end{array}$ & $\begin{array}{l}\mathrm{SCCO}_{2} \text { extract without solvent }- \text { total yield } 7.3 \% \\
\mathrm{SCCO}_{2} \text { extract with solvent - total yield } 51 \% \\
\text { Soxhlet extract - total yield } 39.5 \%\end{array}$ & Paviani et al., (2012) \\
\hline Brazil & $\begin{array}{l}\text { Yes } \\
{ }^{*} \text { Ethanol }\end{array}$ & No & $\begin{array}{l}\mathrm{T}-60^{\circ} \mathrm{C} \\
\mathrm{P}-5,10,15,20 \mathrm{MPa}\end{array}$ & $\begin{array}{l}\mathrm{SCCO}_{2} \text { extract - DPPH activity }(27-93 \%), \mathrm{O}_{2} \text { scavenging activity } \\
(73 \%), \mathrm{OH} \text { scavenging activity }(65 \%)\end{array}$ & Wang et al., (2004) \\
\hline
\end{tabular}


Idrus et al. / Malaysian Journal of Fundamental and Applied Sciences Vol. 14, No. 4 (2018) 387-396

\begin{tabular}{|c|c|c|c|c|c|}
\hline Brazil & No & Ethanol & $\begin{array}{l}T-40-50^{\circ} \mathrm{C} \\
P-250,350,400 \text { bar } \\
F R-6 \mathrm{~g} / \mathrm{min} \\
\mathrm{SC}-1-2 \%\end{array}$ & $\begin{array}{l}\mathrm{SCCO}_{2} \text { extract at } 50^{\circ} \mathrm{C}, 300 \mathrm{bar}, 1 \% \mathrm{EtOH}-\text { Artepillin } \mathrm{C} \text { conc } \\
(8.98 \mathrm{~g} / 100 \mathrm{~g}) \& \text { p-coumaric acid }(0.4 \mathrm{~g} / 100 \mathrm{~g})\end{array}$ & Machado et al., (2015) \\
\hline Brazil & $\begin{array}{l}\text { Yes } \\
{ }^{*} \text { Ethanol }\end{array}$ & No & $\begin{array}{l}\mathrm{T}-60^{\circ} \mathrm{C} \\
\mathrm{P}-150,200,250,300 \mathrm{bar} \\
\mathrm{FR}-1 \mathrm{~g} / \mathrm{min}\end{array}$ & $\begin{array}{l}\mathrm{SCCO}_{2} \text { extract at } 60^{\circ} \mathrm{C}, 150-350 \text { bar resulted in a total yield of } 3.82- \\
13.07 \%\end{array}$ & Paviani et al., (2010) \\
\hline Brazil & $\begin{array}{l}\text { Yes } \\
{ }^{*} \text { Ethanol }\end{array}$ & No & $\begin{array}{l}\mathrm{T}-60^{\circ} \mathrm{C} \\
\mathrm{P}-5,10,15,20 \mathrm{MPa}\end{array}$ & $\begin{array}{l}\mathrm{SCCO}_{2} \text { extract - suppress lipid peroxidation \& increase in antioxidant } \\
\text { enzyme activity }\end{array}$ & Wang et al., (2006) \\
\hline Brazil & No & $\begin{array}{l}\text { Ethanol } \\
\text { Water }\end{array}$ & $\begin{array}{l}\mathrm{T}-50^{\circ} \mathrm{C} \\
\mathrm{P}-250 \mathrm{bar} \\
\mathrm{FR}-1.65 \mathrm{~g} / \mathrm{min} \\
\mathrm{SC}-0.79 \mathrm{~g} / \mathrm{min}\end{array}$ & $\begin{array}{l}\mathrm{SCCO}_{2} \text { extract resulted in a total yield of } 53.5 \% \\
\text { Soxhlet extract resulted in a total yield of } 44.7 \%\end{array}$ & Monroy et al., (2017) \\
\hline
\end{tabular}


In recent decades, $\mathrm{SC}-\mathrm{CO}_{2}$ extraction coupled with the chromatographic method has been introduced, which is useful in extraction and direct quantification of highly volatile compounds, which also helps to reduce the process time needed (Mendiola et al., 2005).

$\mathrm{CO}_{2}$ used in this extraction process can also be recycled or reused, hence minimizing the waste production, particularly in the large-scale $\mathrm{SC}-\mathrm{CO}_{2}$ extraction process. SC- $\mathrm{CO}_{2}$ extraction can be applied in different scales of production, starting from the analytical scale which requires only less than a gram of sample, to preparative scales which needs several hundred grams of sample, and lastly to large industrial scale which can use tonnes of the sample to operate (Sahena et al., 2009). The $\mathrm{SC}-\mathrm{CO}_{2}$ extraction process can also provide important information regarding the extraction process and mechanisms which provide vital information for scientists to quantitatively assess, evaluate and optimize the efficiency of whole extraction process (Sahena et al., 2009).

\section{SC- $\mathrm{CO}_{2}$ VS CONVENTIONAL EXTRACTION}

In food and natural product area, comparison on the performance of SC- $\mathrm{CO}_{2}$ extraction and conventional extraction techniques were widely studied by many researchers. $\mathrm{SC}-\mathrm{CO}_{2}$ extraction has been particularly evaluated in comparison with solid-liquid extraction, hydrodistillation, soxhlet extraction, solvent extraction and ultrasound assisted extraction. $\mathrm{SC}-\mathrm{CO}_{2}$ extraction has been reported to have faster extraction time and higher recovery as compared to hydrodistillation for extraction of essential oil of V.officinalis. However, contrarily hydrodistillation method yielded a better number of volatile compounds extracted as compare to $\mathrm{SC}-\mathrm{CO}_{2}$ extraction method which may due to loss of several volatile compounds during depressurization step in the process (Safaralie et al., 2008).

Additionally, $\mathrm{SC}-\mathrm{CO}_{2}$ extraction had produced more enriched phenolic compounds as compared to solid-liquid extraction in the extraction of grape pomace (Pinelo et al., 2007). However, the composition of the extracts reported was not similar. $\mathrm{SC}-\mathrm{CO}_{2}$ extraction yielded simpler phenolics while solid-liquid extraction resulted in the higher amount of proanthocyanidins content Moreover, SC- $\mathrm{CO}_{2}$ extract demonstrated higher antiradical and antimicrobial activity compared to that in conventional techniques extract (Liu et al., 2009).

Furthermore, $\mathrm{SC}-\mathrm{CO}_{2}$ extraction resulted in similar yield as compared to hot hexane extraction (Wang et al., 2007). SC-CO extraction method can reach a $97-100 \%$ recoveries for a wide range of food products extract, for instance, puff-dried product, potato chips and seeds. There was no significant difference in fatty acids composition of beef sample extract yielded from $\mathrm{SC}-\mathrm{CO}_{2}$ compared to that of conventional extraction method as per the nutritional labelling and education act (NLEA) procedure (King et al., 1996). Comparable results of fatty acid contents in beef and bakery samples extract were reportedly obtained from acid hydrolysis solvent extraction and SC$\mathrm{CO}_{2}$ extraction method. However, $\mathrm{SC}-\mathrm{CO}_{2}$ have recovered significantly higher concentration of lipids and fatty acids in seaweed sample as compared to chloroform and methanol soxhlet extraction (Eller \& King, 1998).

Satisfactory results were recorded for fat content and fatty acid profile in dairy product extracted with $\mathrm{SC}-\mathrm{CO}_{2}$, which recovery was between $83.1 \%$ and $96.4 \%$. Similarly, the extraction yield of some bakery products using $\mathrm{SC}-\mathrm{CO}_{2}$ was similar to that of the conventional extraction method (Wu et al., 2009). To conclude, various researches mentioned above had demonstrated $\mathrm{SC}-\mathrm{CO}_{2}$ extraction could be a better alternative or replacement for conventional extraction methods for a large variety of natural samples (Wu et al., 2009). Although the method has slight drawback with cost-effectiveness for low volume products, a various study has been carried out to overcome the mentioned disadvantages.

Notably, SC-CO $\mathrm{CO}_{2}$ extraction of propolis sample has also been compared to several other extraction techniques such as Soxhlet extraction, maceration, and ultrasound extraction. Lee et al., (2007) has reported that the $\mathrm{SC}-\mathrm{CO}_{2}$ extraction method resulted in better recovery at $40 \%$ wt. as compared to soxhlet ethyl-acetate extraction only at $16.9 \%$ wt. The report also mentioned that the $\mathrm{SC}-\mathrm{CO}_{2}$ method has produced the extract purity twice as high the compared to Soxhlet extraction methods. $\mathrm{SC}-\mathrm{CO}_{2}$ extraction was compared to Soxhlet extraction and maceration process in a study by Biscaia \& Ferreira (2009) which has recorded the highest yield for $\mathrm{SC}-\mathrm{CO}_{2}$ extraction at $24.8 \% \mathrm{w} / \mathrm{w}$, while for Soxhlet extraction, at $73 \% \mathrm{w} / \mathrm{w}$. De Zordi et al., (2014) stated that extraction pressure and time affect the extraction of lipophilic components from propolis sample most significantly, while temperature has less effect. They obtained the highest yield of $14.3 \%$ using SC- $\mathrm{CO}_{2}$ extraction at $317 \mathrm{bar}, 45^{\circ} \mathrm{C}$ and $6.5 \mathrm{~h}$ of experimental time (with a gas flow of $2 \mathrm{~L} / \mathrm{min}$ at room conditions of $\mathrm{T}$ and $\mathrm{P}$ ). There was a different composition of flavones and phenolic components observed between both $\mathrm{SC}-\mathrm{CO}_{2}$ and conventional extraction products. The study suggested that $\mathrm{SC}-\mathrm{CO}_{2}$ extraction process can be utilized as pre-treatment of crude propolis for further ethanolic extraction and as a method to yield new kind of lipophilicenriched propolis extract.

\section{CONCLUSION}

In this mini review, the interest in the application of $\mathrm{SC}-\mathrm{CO}_{2}$ extraction for propolis sample has been discussed. Apparently, researches on $\mathrm{SC}-\mathrm{CO}_{2}$ extraction of propolis is growing enormously around the globe. The aim of this review is to summarize all available literature on the application of this advanced, green and promising technique to extract propolis sample which is known to contain various beneficial health compounds as well as to discuss related matters including principle and advantages of $\mathrm{SC}-\mathrm{CO}_{2}$ extraction. Information presented in this short review may provide current information and insightful details regarding $\mathrm{SC}-\mathrm{CO}_{2}$ propolis extraction for future development and improvement.

\section{ACKNOWLEDGEMENT}

Authors thank Research University Grant (Q.J130000.2509.16H87 \& Q.J130000.3009.01M10) from Universiti Teknologi Malaysia for supporting this work.

\section{REFERENCES}

Abu-Mellal, A., Koolaji, N.R., Duke, K., et al., 2012. Prenylated cinnamate and stilbenes from Kangaroo Island propolis and their antioxidant activity. Phytochemistry, 77, 251-259.

Ahn, M. R., Kunimasa, K., Ohta, T., Kumazawa, S., Kamihira, M., Kaji, K., \& Nakayama, T. (2007). Suppression of tumor-induced angiogenesis by Brazilian propolis: major component artepillin $\mathrm{C}$ inhibits in vitro tube formation and endothelial cell proliferation. Cancer Letters, 252(2), 235243.

Almutairi, S., Eapen, B., Chundi, S. M., Akhalil, A., Siheri, W., Clements, C. \& Edrada-Ebel, R. (2014). New anti-trypanosomal active prenylated compounds from African propolis. Phytochemistry Letters, 10, 35-39.

Ameer, K., Shahbaz, H. M., \& Kwon, J. H. (2017). Green extraction methods for polyphenols from plant matrices and their byproducts: A review. Comprehensive Reviews in Food Science and Food Safety, 16, 295-315.

Aziz, A. H. A., Yunus, M. A. C., Arsad, N. H., Lee, N. Y., Idham, Z., \& Razak, A. Q. A. (2016). Optimization of supercritical carbon dioxide extraction of Piper Betel Linn leaves oil and total phenolic content. IOP Conference Series: Materials Science and Engineering, 162(1), 012031.

Azizi, C. M., \& Ismail, N. A. (2008). Optimization of removing of free fatty acid content Jatropha curcas L. seed oil using experimental design. Journal of Chemical and Natural Resources Engineering, Special Edition: 36-48.

Babovic, N., Djilas, S., Jadranin, M., Vajs, V., Ivanovic, J., Petrovic, S., \& Zizovic, I. (2010). Supercritical carbon dioxide extraction of antioxidant fractions from selected Lamiaceae herbs and their antioxidant capacity. Innovative Food Science \& Emerging Technologies, 11(1), 98-107.

Biscaia, D., \& Ferreira, S. R. (2009). Propolis extracts obtained by low pressure methods and supercritical fluid extraction. The Journal of Supercritical Fluids, 51(1), 17-23 
Bozan, B., \& Temelli, F. (2003). Extraction of poppy seed oil using supercritical $\mathrm{CO}_{2}$. Journal of Food Science, 68(2), 422-426.

Bueno-Silva, B., Marsola, A., Ikegaki, M., Alencar, S. M., \& Rosalen, P. L. (2017). The effect of seasons on Brazilian red propolis and its botanical source: chemical composition and antibacterial activity. Natural Product Research, 31(11), 1318-1324.

Catchpole, O. J., Grey, J. B., Mitchell, K. A., \& Lan, J. S. (2004). Supercritical antisolvent fractionation of propolis tincture. The Journal of Supercritical Fluids, 29(1), 97-106.

Chemat, F., \& Khan, M. K. (2011). Applications of ultrasound in food technology: processing, preservation and extraction. Ultrasonics Sonochemistry, 18(4), 813-835.

Chen, C. R., Lee, Y. N., Chang, C. M. J., Lee, M. R., \& Wei, I. C. (2007). Hotpressurized fluid extraction of flavonoids and phenolic acids from Brazilian propolis and their cytotoxic assay in vitro. Journal of the Chinese Institute of Chemical Engineers, 38(3), 191-196.

Chen, C. R., Shen, C. T., Wu, J. J., Yang, H. L., Hsu, S. L., \& Chang, C. M. J. (2009). Precipitation of sub-micron particles of 3,5-diprenyl-4hydroxycinnamic acid in Brazilian propolis from supercritical carbon dioxide anti-solvent solutions. The Journal of Supercritical Fluids, 50(2), 176-182.

Choi, Y. M., Noh, D. O., Cho, S. Y., Suh, H. J., Kim, K. M., \& Kim, J. M. (2006). Antioxidant and antimicrobial activities of propolis from several regions of Korea. LWT-Food Science and Technology, 39(7), 756-761.

Custodio, A. R., Ferreira, M., Negri, G., \& Salatino, A. (2003). Clustering of comb and propolis waxes based on the distribution of aliphatic constituents. Journal of the Brazilian Chemical Society, 14(3), 354-357.

Danlami, J. M., Zaini, M. A. A., Arsad, A., \& Yunus, M. A. C. (2015). A parametric investigation of castor oil (Ricinus comminis L) extraction using supercritical carbon dioxide via response surface optimization. Journal of the Taiwan Institute of Chemical Engineers, 53, 32-39.

De Zordi, N., Cortesi, A., Kikic, I., Moneghini, M., Solinas, D., Innocenti, G., \& Dall'Acqua, S. (2014). The supercritical carbon dioxide extraction of polyphenols from propolis: a central composite design approach. The Journal of Supercritical Fluids, 95, 491-498.

Dejoye, C., Vian, M. A., Lumia, G., Bouscarle, C., Charton, F., \& Chemat, F. (2011). Combined extraction processes of lipid from Chlorella vulgaris microalgae: microwave prior to supercritical carbon dioxide extraction. International Journal of Molecular Sciences, 12(12), 9332-9341.

Destandau, E., Michel, T., \& Elfakir, C. (2013). Microwave-assisted extraction. RSC Publishing, Cambridge, UK.

Eller, F. J., \& King, J. W. (1998). Supercritical $\mathrm{CO}_{2}$ extraction of fat: Comparison of gravimetric and GC-FAME methods. Journal of Agricultural and Food Chemistry, 46(9), 3657-3661.

El-Shemy, H. A., Aboul-Soud, M. A. M., Nassr-Allah, A. A., Aboul-Enein, K M., Kabash, A., \& Yagi, A. (2010). Antitumor properties and modulation of antioxidant enzymes' activity by aloe vera leaf active principles isolated via supercritical carbon dioxide extraction. Current Medicinal Chemistry, 17(2), 129-138.

Engelhardt, H., Zapp, J., \& Kolla, P. (1991). Sample preparation by supercritical fluid extraction in environmental food and polymer analysis. Chromatographia, 32(11-12), 527-537.

Erdogan, S., Ates, B., Durmaz, G., Yilmaz, I., \& Seckin, T. (2011). Pressurized liquid extraction of phenolic compounds from Anatolia propolis and their radical scavenging capacities. Food and Chemical Toxicology, 49(7), 1592-1597.

Favati, F., King, J. W., \& Mazzanti, M. (1991). Supercritical carbon dioxide extraction of evening primrose oil. Journal of the American Oil Chemists Society, 68(6), 422-427.

Fernández, M. P., Rodriguez, J. F., García, M. T., De Lucas, A., \& Gracia, I. (2008). Application of supercritical fluid extraction to brewer's spent grain management. Industrial \& Engineering Chemistry Research, 47(5), 16141619.

Fiori, L. (2010). Supercritical extraction of grape seed oil at industrial-scale: Plant and process design, modeling, economic feasibility. Chemical Engineering and Processing: Process Intensification, 49(8), 866-872.

Funakoshi-Tago, M., Ohsawa, K., Ishikawa, T., Nakamura, F., Ueda, F., Narukawa, Y., \& Kasahara, T. (2016). Inhibitory effects of flavonoids extracted from Nepalese propolis on the LPS signaling pathway. International Immunopharmacology, 40, 550-560.

Hamzah, N., \& Leo, C. P. (2015). Microwave-assisted extraction of trigona propolis: the effects of processing parameters. International Journal of Food Engineering, 11(6), 861-870.

Hartati, H., Salleh, L. M., \& Yunus, M. A. C. (2016). The effect of supercritical $\mathrm{CO}_{2}$ on the antioxidant activity of the Swietenia mahagoni seed extract by Box-Behnken design. In Proceeding International Conference on Mathematic, Science, Technology, Education and their Applications, 3-4 October 2016, Makassar, Indonesia. Indonesia: Fakultas MIPA Universitas Negeri Makassar, pp. 383-388
Herrero, M., Cifuentes, A., \& Ibañez, E. (2006). Sub- and supercritical fluid extraction of functional ingredients from different natural sources: Plants, food-by-products, algae and microalgae: A review. Food Chemistry, 98(1), 136-148.

Herrero, M., Mendiola, J. A., Cifuentes, A., \& Ibáñez, E. (2010). Supercritical fluid extraction: Recent advances and applications. Journal of Chromatography A, 1217(16), 2495-2511.

Ixtaina, V. Y., Vega, A., Nolasco, S. M., Tomás, M. C., Gimeno, M., Bárzana, E., \& Tecante, A. (2010). Supercritical carbon dioxide extraction of oil from Mexican chia seed (Salvia hispanica L.): Characterization and process optimization. The Journal of Supercritical Fluids, 55(1), 192-199.

Kalani, M., \& Yunus, R. (2011). Application of supercritical antisolvent method in drug encapsulation: A review. International Journal of Nanomedicine, 6, 1429-1442.

King, J. W., Eller, F. J., Snyder, J. M., Johnson, J. H., McKeith, F. K., \& Stites, C. R. (1996). Extraction of fat from ground beef for nutrient analysis using analytical supercritical fluid extraction. Journal of Agricultural and Food Chemistry, 44(9), 2700-2704.

Kumazawa, S., Hamasaka, T., \& Nakayama, T. (2004). Antioxidant activity of propolis of various geographic origins. Food Chemistry, 84(3), 329-339.

Kumoro, A. C., \& Hasan, M. (2007). Supercritical carbon dioxide extraction of andrographolide from Andrographis paniculata: Effect of the solvent flow rate, pressure, and temperature. Chinese Journal of Chemical Engineering, 15(6), 877-883

Lang, Q., \& Wai, C. M. (2001). Supercritical fluid extraction in herbal and natural product studies - A practical review. Talanta, 53(4), 771-782.

Lee, M. L., \& Markides, K. E. (Eds.). (1990). Analytical supercritical fluid chromatography and extraction. Provo: Chromatography Conferences.

Lee, Y. N., Chen, C. R., Yang, H. L., Lin, C. C., \& Chang, C. M. J. (2007). Isolation and purification of 3,5-diprenyl-4-hydroxycinnamic acid (artepillin C) in Brazilian propolis by supercritical fluid extractions. Separation and Purification Technology, 54(1), 130-138.

Liu, X., Zhao, M., Wang, J., \& Luo, W. (2009). Antimicrobial and antioxidant activity of emblica extracts obtained by supercritical carbon dioxide extraction and methanol extraction. Journal of Food Biochemistry, 33(3), 307-330.

Liza, M. S., Rahman, R. A., Mandana, B., Jinap, S., Rahmat, A., Zaidul, I. S. M., \& Hamid, A. (2010). Supercritical carbon dioxide extraction of bioactive flavonoid from Strobilanthes crispus (Pecah Kaca). Food and Bioproducts Processing, 88(2), 319-326.

Lu, L. C., Chen, Y. W., \& Chou, C. C. (2005). Antibacterial activity of propolis against Staphylococcus aureus. International Journal of Food Microbiology, 102(2), 213-220.

Machado, B. A. S., de Abreu Barreto, G., Costa, A. S., Costa, S. S., Silva, R. P. D., da Silva, D. F., \& Padilha, F. F. (2015). Determination of parameters for the supercritical extraction of antioxidant compounds from green propolis using carbon dioxide and ethanol as co-solvent. PloS One, 10(8), e0134489.

Machado, B. A. S., Silva, R. P. D., de Abreu Barreto, G., Costa, S. S., da Silva, D. F., Brandão, H. N., \& Padilha, F. F. (2016). Chemical composition and biological activity of Extracts obtained by supercritical extraction and ethanolic extraction of brown, green and Red Propolis derived from different geographic regions in Brazil. PloS One, 11(1), e0145954.

Machmudah, S., Sulaswatty, A., Sasaki, M., Goto, M., \& Hirose, T. (2006). Supercritical $\mathrm{CO}_{2}$ extraction of nutmeg oil: Experiments and modeling. The Journal of Supercritical Fluids, 39(1), 30-39.

Manirakiza, P., Covaci, A., \& Schepens, P. (2001). Comparative study on total lipid determination using Soxhlet, Roese-Gottlieb, Bligh \& Dyer, and modified Bligh \& Dyer extraction methods. Journal of Food Composition and Analysis, 14(1), 93-100.

Marcucci, M. C., Ferreres, F., Garcı-Viguera, C., Bankova, V. S., De Castro, S. L., Dantas, A. P. \& Paulino, N. (2001). Phenolic compounds from Brazilian propolis with pharmacological activities. Journal of Ethnopharmacology, 74(2), 105-112.

McHugh, M., \& Krukonis, V. (2013). Supercritical fluid extraction: Principles and practice. Elsevier.

Mello, B. C., Petrus, J. C. C., \& Hubinger, M. D. (2010). Concentration of flavonoids and phenolic compounds in aqueous and ethanolic propolis extracts through nanofiltration. Journal of Food Engineering, 96(4), 533539.

Mendiola, J. A., Marín, F. R., Hernandez, S., Arredondo, B. O., Señoráns, F. J., Ibañez, E., \& Reglero, G. (2005). Characterization via liquid chromatography coupled to diode array detector and tandem mass spectrometry of supercritical fluid antioxidant extracts of Spirulina platensis microalga. Journal of Separation Science, 28(9- 10), 1031-1038.

Mohamed, R. S., \& Mansoori, G. A. (2002). The use of supercritical fluid extraction technology in food processing. Food Technology Magazine, 20, 134-139.

Monroy, Y. M., Rodrigues, R. A., Rodrigues, M. V., Sant'Ana, A. S., Silva, B. S., \& Cabral, F. A. (2017). Brazilian green propolis extracts obtained by 
conventional processes and by processes at high pressure with supercritical carbon dioxide, ethanol and water. The Journal of Supercritical Fluids, 130, 189-197.

Nagai, T., Inoue, R., Inoue, H., \& Suzuki, N. (2003). Preparation and antioxidant properties of water extract of propolis. Food Chemistry, 80(1), 29-33.

Paviani, L. C., Dariva, C., Marcucci, M. C., \& Cabral, F. A. (2010) Supercritical carbon dioxide selectivity to fractionate phenolic compounds from the dry ethanolic extract of propolis. Journal of Food Process Engineering, 33(1), 15-27.

Paviani, L. C., Saito, E., Dariva, C., Marcucci, M. C., Sánchez-Camargo, A. P., \& Cabral, F. A. (2012). Supercritical $\mathrm{CO}_{2}$ extraction of raw propolis and its dry ethanolic extract. Brazilian Journal of Chemical Engineering, 29(2), 243-251

Pellati, F., Prencipe, F. P., Bertelli, D., \& Benvenuti, S. (2013). An efficient chemical analysis of phenolic acids and flavonoids in raw propolis by microwave-assisted extraction combined with high-performance liquid chromatography using the fused-core technology. Journal of Pharmaceutical and Biomedical Analysis, 81, 126-132.

Pereira, C. G., \& Meireles, M. A. A. (2007). Economic analysis of rosemary, fennel and anise essential oils obtained by supercritical fluid extraction. Flavour and Fragrance Journal, 22(5), 407-413.

Pietta, P. G. (2000). Flavonoids as antioxidants. Journal of Natural Products, 63(7), 1035-1042.

Pietta, P. G., Gardana, C., \& Pietta, A. M. (2002). Analytical methods for quality control of propolis. Fitoterapia, 73, S7-S20.

Pinelo, M., Ruiz-Rodríguez, A., Sineiro, J., Señoráns, F. J., Reglero, G., \& Núñez, M. J. (2007). Supercritical fluid and solid-liquid extraction of phenolic antioxidants from grape pomace: a comparative study. European Food Research and Technology, 226(1-2), 199-205.

Raventós, M., Duarte, S., \& Alarcón, R. (2002). Application and possibilities of supercritical $\mathrm{CO} 2$ extraction in food processing industry: an overview. Revista de Agaroquimica y Tecnologia de Alimentos, 8(5), 269-284.

Regueira, M. S., Tintino, S. R., da Silva, A. R. P., do Socorro Costa, M. Boligon, A. A., Matias, E. F., \& Coutinho, H. D. M. (2017). Seasonal variation of Brazilian red propolis: Antibacterial activity, synergistic effect and phytochemical screening. Food and Chemical Toxicology, 107(B), 572-580.

Reverchon, E., \& De Marco, I. (2006). Supercritical fluid extraction and fractionation of natural matter. The Journal of Supercritical Fluids, 38(2), 146-166.

Safaralie, A., Fatemi, S., \& Sefidkon, F. (2008). Essential oil composition of Valeriana officinalis L. roots cultivated in Iran: Comparative analysis between supercritical $\mathrm{CO} 2$ extraction and hydrodistillation. Journal of Chromatography A, 1180(1), 159-164.

Sahena, F., Zaidul, I. S. M., Jinap, S., Karim, A. A., Abbas, K. A., Norulaini, N. A. N., \& Omar, A. K. M. (2009). Application of supercritical $\mathrm{CO}_{2}$ in lipid extraction-a review. Journal of Food Engineering, 95(2), 240-253.

Sanpa, S., Sutjarittangtham, K., Tunkasiri, T., Eitssayeam, S., \& Chantawannakul, P. (2012). Ultrasonic extraction of Thai propolis for antimicrobial and antioxidant properties. Advanced Materials Research, $506,371-374$

Socha, R., Gałkowska, D., Bugaj, M., \& Juszczak, L. (2015). Phenolic composition and antioxidant activity of propolis from various regions of Poland. Natural Product Research, 29(5), 416-422.

Song, K. M., Park, S. W., Hong, W. H., Lee, H., Kwak, S. S., \& Liu, J. R. (1992). Isolation of vindoline from Catharanthus roseus by supercritical fluid extraction. Biotechnology Progress, 8(6), 583-586.

Tai, H. P., \& Kim, K. P. T. (2014). Supercritical carbon dioxide extraction of Gac oil. The Journal of Supercritical Fluids, 95, 567-571.

Teberikler, L., Koseoglu, S., \& Akgerman, A. (2001). Selective extraction of phosphatidylcholine from lecithin by supercritical carbon dioxide/ethanol mixture. Journal of the American Oil Chemists' Society, 78(2), 115-120.

Trusheva, B., Trunkova, D., \& Bankova, V. (2007). Different extraction methods of biologically active components from propolis: A preliminary study. Chemistry Central Journal, 1(1), 13.

Tylkowski, B., Trusheva, B., Bankova, V., Giamberini, M., Peev, G., \& Nikolova, A. (2010). Extraction of biologically active compounds from propolis and concentration of extract by nanofiltration. Journal of Membrane Science, 348(1), 124-130.

USDA (1985) United States Department of Agriculture. United States Standards for Grades of Extracted Honey. Agricultural Marketing Service. Fruit and Vegetable Division. Processed Products Branch. Washington, DC.

Wang, B. J., Lien, Y. H., \& Yu, Z. R. (2004). Supercritical fluid extractive fractionation-study of the antioxidant activities of propolis. Food Chemistry, 86(2), 237-243.

Wang, B. J., Lien, Y. H., Su, C. L., Wu, C. P., \& Yu, Z. R. (2006) Fractionation using supercritical $\mathrm{CO}_{2}$ influences the antioxidant and hepatoprotective activity of propolis against liver damage induced by tert- butyl hydroperoxide. International Journal of Food Science \& Technology, 41(s1), 68-75.

Wang, L., Weller, C. L., Schlegel, V. L., Carr, T. P., \& Cuppett, S. L. (2007). Comparison of supercritical $\mathrm{CO} 2$ and hexane extraction of lipids from sorghum distillers grains. European Journal of Lipid Science and Technology, 109(6), 567-574.

Weinhold, T. D. S., Bresciani, L. F., Tridapalli, C. W., Yunes, R. A., Hense, H., \& Ferreira, S. R. (2008). Polygala cyparissias oleoresin: Comparing $\mathrm{CO}_{2}$ and classical organic solvent extractions. Chemical Engineering and Processing: Process Intensification, 47(1), 109-117.

Wu, J. J., Shen, C. T., Jong, T. T., Young, C. C., Yang, H. L., Hsu, S. L., \& Shieh, C. J. (2009). Supercritical carbon dioxide anti-solvent process for purification of micronized propolis particulates and associated anti-cancer activity. Separation and Purification Technology, 70(2), 190-198.

Wu, J., \& Luyu, Q. (2000). Supercritical multiple extraction of bee glue. Chinese Patent, CN, 1.

You, G. S., Lin, S. C., Chen, C. R., Tsai, W. C., Chang, C. J., \& Huang, W. W. (2002). Supercritical carbon dioxide extraction enhances flavonoids in water-soluble propolis. Journal of the Chinese Institute of Chemical Engineers, 33(3), 233-241.

Yunus, M. A. C., binti Idham, Z., \& Morad, N. A. (2015, May). Optimisation of squalene from palm oil mesocarp using supercritical carbon dioxide. In 2015 10th Asian Control Conference (ASCC), 31 May-3 June 2015 Sabah, Malaysia. Malaysia: IEEE, pp. 1-6.

Zuknik, M. H., Norulaini, N. N., \& Omar, A. M. (2012). Supercritical carbon dioxide extraction of lycopene: A review. Journal of Food Engineering, 112(4), 253-262. 